\title{
Entrepreneurial Motivation and Challenges: A Study on Women Entrepreneurs in Sylhet City
}

\section{Fathema Farjana Hani}

Lecturer, Department of Business Administration, North East University Bangladesh, Telihaor, Sheikhghat, Sylhet- 3100, BANGLADESH

*Corresponding Contact:

Email: farjanahani@gmail.com

Cell Phone: +8801722353862

\begin{abstract}
Women entrepreneurship is not only the way of poverty alleviation but also the key to a nation's overall advancement. This study attempts to explore several aspects of them. It emphasized on the profile of women entrepreneurs, identifying the motivation behind their entrepreneurial career, and pinpointing the challenges they are facing. The study conducted on 50 women entrepreneurs of Sylhet city. Both primary and secondary data was used. The profile of the women entrepreneurs shows information about their age, educational qualification, marital status, type of family they belongs to. Type and ownership of their business, amount and sources of start-up capital, no. of employees and their future career plan is also included in the profile. The study identified that $31 \%$ of the respondents are self-motivated to be entrepreneurs. The reasons to start business consist of- be self-dependent, extra income for the family, to run the family business, for economic freedom, etc. The study also finds out challenges in starting and continuing business of women entrepreneurs that can obstruct the smooth functioning of it. Some of the challenges are- conservative social attitude, gender discrimination, lack of skills and training facilities, infrastructural problems, etc. The study also reveals that the women entrepreneurs in Sylhet city are getting the support of family members, and they can manage start-up capital. This study has some implication for researchers in the area of entrepreneurship and women entrepreneurship.
\end{abstract}

Keywords: Women entrepreneurs, Motivation, Challenges, Self-dependent, Gender discrimination

\section{INTRODUCTION}

For the functioning of our body, every part of it has to conduct properly. Like as, for the advancement of a country, the human resources have to work together which comprises male and female. Participation of women in the country's economic affairs is imperative. Active participation of women can bring dynamism in growth. Incorporation of women, in the economic activity, can ensure development discourse. Enrichment of women 
entrepreneurships are the means of a healthy nation. Engaging in entrepreneurship provides women a platform of income generation, to uplift their social status, works against existing gender biasness, \& contribution in the betterment of society.

According to (Ahmed et al., 2012) no one in this world is the boss of his own, except the "Entrepreneurs" who are regarded as the most value adding people to the society.

According to (Reza et al., 2014) Bangladesh is a resource-limited and overpopulated country where society is highly stratified, services and opportunities are determined by gender, class and location. However, women make nearly half of the population which means huge potential to be utilized for socio-economic development of the country. Development and enrichment of women entrepreneurship are the means of promoting national competitiveness and sustainability.

Anis and Hasan (2013) states that, the overall economic development of a country depends on many sides. The cumulative sectoral economic growth of various industries stimulates the pace of development in an economy. The women are the large part of our country about half of the total population. This large part of our population can largely produce significant support to the overall development of the country.

As noted by (Chowdhury and Rahman, 2014) Sylhet is the highest foreign remittance earning area in Bangladesh because near about half a million people of this area are now living in abroad. So, in a sense, people are more solvent than other areas and the availability of the fund is easy to run a business. As a result, women in Sylhet are interested to utilize the fund and want to make their status.

Despite of complex, male-dominated, and stratifies structure, women are going forward to show their worth. Day by day, they are increasing in the number who continually works for the progress of the country. Those initiatives are crucial for economic independence of a nation. Women are now more conscious about their position and status. Now, they have the perseverance to overcome the obstacles and gain the success. The government has to take necessary steps to utilize that part of the human resource.

Kaushik (2013) opines as entrepreneurship is the core of economic development. Entrepreneur is a key factor of entrepreneurship. In present time women are an emerging economic force. Women constitute the family, which leads to society and family.

\section{LITERATURE REVIEW}

Holt (2000) finds the term entrepreneur may be properly applied to those who incubate new ideas, start enterprises based on those ideas, and provide added value to society based on their independent initiative. Women entrepreneurs are those who are ready for confronting risk and have persistence to survive in a competitive business world.

According to (Khanka, 2009) women entrepreneurs are those women who think of a business enterprise, initiate it, organize and combine the factors of production, operate the enterprise and undertake risks and handle economic uncertainty involved in running a business enterprise. Different authors study the motivating factors of women entrepreneurs in their way.

Khanka (2009) argues that women are plunged into business for both pull and push factors. Pull factors imply the factors that encourage women to start an occupation or venture with an urge to do something independently. Push factors refer to those factors that compel to take up their own business to tide over their economic difficulties and responsibilities. The pivotal role that women entrepreneurs play in an economy to the advancement of a nation is crucial. They can uplift the status of women, as well as can contribute in nation's economy. Different authors' have shown the social and economic impact of women entrepreneur in their way. 
Singh (2012) founds that which encourages women to have an independent occupation and stands on their own legs? A sense towards independent decision-making on their life and career is the motivational factor behind this urge.

Nawaz (2009) analyzes various factors of rural women entrepreneurs in Bangladesh based on institutional theory that have three main pillars- regulative, cognitive and normative. Regulative factors refer to different rules of the Government that facilitate women entrepreneurship development in rural Bangladesh. Normative systems are typically imposing constraints on social behavior. But at the same time they enable social action. Cognitive factors associated with internal issues of women's life and their environmental interaction. Nawaz provides recommendations to improve women entrepreneurship in rural Bangladesh.

Women entrepreneurs are handicapped by the society as the society binds their role as daughter, wife and mother. Women are treating as homemakers within the four walls. Women, who want to survive as professionals, stumble in her every step. The lack of encouragement creates hindrance in their way of success. Besides the encouraging factors, authors are also studying the obstacles of women entrepreneurs. Which obstacles must vanished to reap the reward.

Charantimath (2012) argues that it is not always easy for women to find jobs that will be compatible with their family responsibilities and household chores. Thus many women are attracted by the idea of self-employment in enterprises adjoining their house premises, with flexible hours, which allows them to take care of both home and business. Small-scale enterprises represent an important means of income for women in developing countries. They provide employment and income to alleviate poverty.

Siddiqui (2012) points out some of the major problems of women entrepreneurs in India, these are- women's family obligations, Gender inequality, Problem of Finance, Low-level risk taking attitude, and the male-female competition. The paper concludes that the problems of women entrepreneurs can be eradicated by appropriate training, incentives, encouragement and motivation, social recognition of their entrepreneurial abilities, and family's moral support. Additionally the tradition, customs, socio cultural values, ethics, motherhood, subordinates to husbands and men, physically weak, hard work areas, feeling of insecurity, cannot be tough etc. are some peculiar problems that the Indian women are coming across while they jump into entrepreneurship.

Khanka (2009) argues that women entrepreneurs encounter two sets of constraints, viz., general problems of entrepreneurs and problems specific to women entrepreneurs. He identified some problems that hold the women back from entering into business: problem of finance, scarcity of raw material, stiff competition, limited mobility, family ties, lack of education, male-dominated society, little risk-bearing ability, inadequate infrastructural facilities, shortage of power, high cost of production, social attitude, low need for achievement and socio-economic constraints.

According to (Kaushik, 2013) women have been taking an interest in recent year in selfbusiness. In the process of Entrepreneurship, women have to face various problems and these problems, get doubled because of her dual role as earner and homemakers.

As women entrepreneurship bring status to a women, on the other side their initiative helps to drive the wheel of the nation. This contributes to the nation's advancement. Without these womenfolk footsteps the journey toward progress is will remain incomplete.

\section{OBJECTIVES}

The study aims to explore:

- To prepare a profile of women entrepreneurs in Sylhet city

- To identify the motivation behind their entrepreneurial venture

- To find out the challenges confronted by women entrepreneurs in Sylhet city. 


\section{Methodology}

This paper is prepared by using both primary and secondary data and information. Primary data collected from surveys conducted by questionnaire. The questionnaire was framed by using both open and close ended questions. The questionnaire was consists of three parts: a) profile of women entrepreneurship and information related to business enterprise, b) factors that motivated them c) problems faced by them. The first part focused on accomplishing the first objective of the paper to prepare a profile of women entrepreneurs in Sylhet city and their about their business. This section specifically contain information about their age, educational qualification, marital status, type of family they belongs to, and, type, forms of ownership, duration, nature, initial investment, sources of start-up capital, monthly income, number of employees, and their future career plan. The second part of the questionnaire was to achieve the second objective of the study to identify the motivation behind their entrepreneurial career. A list of motivating factors was provided and the respondents were asked to identify most compelling one. They also provided with the option to mention any unspecified reason on the list. The result of the first and second sections were tabulated and presented on percentage basis.

The last part was to achieve the third objective to identify the hurdles faced by women entrepreneurs. Here 5 point Likert Scale was used to point the obstacles faced by them. For analyzing this part Mean and Standard Deviation is used. Secondary information is collected from different books, journals and websites. Purposive sampling is applied in this research. Therefore, the respondents for questionnaire survey were selected who are conducting their business for one year in Sylhet city. The questionnaire survey conducted among 50 women entrepreneurs from Sylhet city. Face-to-face interviews were conducted. Ten respondents were interviewed in-depth to have closer view on the problems faced by them. Both qualitative and quantitative procedures of data collection were applied. In this study some tabular analyses have been used for processing and analyzing the data. Tabulated data were analyzed by using Sum, Mean, Standard Deviation, Percentage etc. With the help of software packages namely MS word, MS Excel.

\section{RESEARCH FIndings}

\section{Profile of the women entrepreneurs and their business}

Table 1: Profile of the women entrepreneurs in Sylhet city

\begin{tabular}{|c|c|c|c|}
\hline \multicolumn{2}{|c|}{ Basic information } & No. of respondents & Percentage \\
\hline \multirow[t]{4}{*}{ Age } & $20-30$ years & 22 & 44 \\
\hline & $31-40$ years & 21 & 42 \\
\hline & $41-50$ years & 6 & 12 \\
\hline & Over 50 years & 1 & 2 \\
\hline \multicolumn{2}{|r|}{ Total } & 50 & 100 \\
\hline \multirow{4}{*}{$\begin{array}{l}\text { Educational } \\
\text { qualification }\end{array}$} & Below HSC & 29 & 58 \\
\hline & HSC pass & 15 & 30 \\
\hline & Graduate & 5 & 10 \\
\hline & Post-graduation & 1 & 2 \\
\hline \multicolumn{2}{|r|}{ Total } & 50 & 100 \\
\hline \multirow[t]{4}{*}{ Marital Status } & Married & 31 & 62 \\
\hline & Unmarried & 15 & 30 \\
\hline & Divorced & 3 & 6 \\
\hline & Widowed & 1 & 2 \\
\hline \multicolumn{2}{|r|}{ Total } & 50 & 100 \\
\hline \multirow{2}{*}{$\begin{array}{l}\text { Type of family } \\
\text { they belong to }\end{array}$} & Nuclear & 33 & 66 \\
\hline & Joint family & 17 & 34 \\
\hline Total & & 50 & 100 \\
\hline
\end{tabular}

Source: Calculated from primary data 
Table- 1 shows that, among the women entrepreneurs interviewed, $44 \%$ belong to the age group 20-30 years, age group 31-40 years contain $42 \%$. Women entrepreneurs belong to rest two groups (41-50 years, over 50 years) are $12 \%$ and $2 \%$. This percentage distribution of the women entrepreneurs indicates that most of the women entrepreneurs are young in Sylhet city.

From the survey it is found that, educational qualification is not so good among the women entrepreneurs. 58\% of the respondents are below HSC which is not encouraging. But here we can see in the table that, graduate $(10 \%)$ and post graduate $(2 \%)$ are also involving in field of entrepreneurship without finding a job. Only 30\% of the women are HSC pass. For facing risk and uncertainty of entrepreneurial career educational qualification as well as training is a prerequisite. In Bangladesh, the socio-cultural perspective and the custom bind the women to have the consent of husband before taking any decision. The survey result shows that, $62 \%$ women are married and also they are entrepreneurs. From this it can be said that, now husbands are helpful in their wives profession and women are gradually interested to continue their enterprise even after handling the family. Only 30\% are unmarried. Divorced and widowed are $6 \%$ and $2 \%$ respectively. One of the divorced interviewees expressed: "My enterprise helps me when I was alone after my husband's death. I can support myself in every spheres of my life." From this it can be said that, women entrepreneurship is a helping hand for women.

The survey result shows that $66 \%$ of the women entrepreneurs are from nuclear family, and $34 \%$ are from joint family. It indicates that gradually nuclear families are increasing, and most of the women entrepreneurs are from nuclear family.

Table 2: Type of business

\begin{tabular}{|l|c|c|}
\hline \multicolumn{1}{|c|}{ Type of business } & No. of respondents & Percentage \\
\hline Tailoring & 24 & 48 \\
\hline Handicrafts & 4 & 8 \\
\hline Boutique shop & 3 & 6 \\
\hline Beauty parlor & 2 & 4 \\
\hline Catering & 1 & 2 \\
\hline Clothing business & 8 & 16 \\
\hline Flower business & 1 & 2 \\
\hline Grocery shop & 0 & 0 \\
\hline Confectionary and bakery shop & 1 & 2 \\
\hline Agro based/livestock & 1 & 2 \\
\hline Nursery & 1 & 2 \\
\hline IT services & 0 & 0 \\
\hline Others & 4 & 8 \\
\hline Total & 50 & 100 \\
\hline
\end{tabular}

Source: Calculated from primary data

From the respondents it is found that (Table-2), most of the women entrepreneurs are engaged in traditional female occupation like tailoring $(48 \%)$, clothing $(16 \%)$, handicrafts $(8 \%)$, beauty parlor $(4 \%)$, and boutique shop (6\%). Catering and flower business contain ( $2 \%)$ each. Confectionary and bakery shop, agro-based/livestock, and nursery contains the same percentage each (2\%). Among the respondents no one in the grocery shop and IT service. From this it can be said that, women are lagged behind from technology. Others (8\%) consist of medicine store and cosmetic shop. It is encouraging that, day by day women are interested in the outside of the traditional boundary like medicine store or nursery. Though, it is a small percent. 
Table 3: Forms of business ownership

\begin{tabular}{|c|c|c|c|c|}
\hline \multicolumn{3}{|c|}{ Forms of business ownership } & No. of respondents & Percentage \\
\hline \multicolumn{3}{|c|}{ Sole proprietorship } & 40 & 80 \\
\hline \multirow[t]{2}{*}{ Partnership } & With family & 07 & \multirow[t]{2}{*}{10} & \multirow[t]{2}{*}{20} \\
\hline & With friend & 03 & & \\
\hline \multicolumn{3}{|c|}{ Cooperative Society } & 0 & 0 \\
\hline \multicolumn{3}{|c|}{ Private Limited Company } & 0 & 0 \\
\hline \multicolumn{3}{|c|}{ Total } & 50 & 100 \\
\hline
\end{tabular}

Source: Calculated from primary data

Table- 3 shows, as the form of business ownership sole proprietorship consists of $80 \%$ and in the dominant position. $10(20 \%)$ of the respondents are in partnership form (7 of it with family members and 3 with friends). From this it can be said that women entrepreneurs in Sylhet city are want to conduct their business by their own accord. That is sole proprietorship is operated and managed by the owner.

Table 4: Sources of start-up capital

\begin{tabular}{|c|c|c|}
\hline Sources & No. of respondents & Percentage \\
\hline Own fund & 7 & 14 \\
\hline Finance from family & 32 & 64 \\
\hline Finance from friend & 2 & 4 \\
\hline Finance from other persons & 1 & 2 \\
\hline Loan from commercial bank & 1 & 2 \\
\hline Loan from financial institutions & 5 & 10 \\
\hline Both from family and another person & 1 & 2 \\
\hline Both own fund and finance from family & 1 & 2 \\
\hline Total & 50 & 100 \\
\hline
\end{tabular}

Source: Calculated from primary data

For the smooth functioning of an enterprise, adequate capital is a must. According to (Charantimath, 2012) before starting an industrial unit, it is necessary that an entrepreneur estimate its financial requirement. He should scientifically calculate the fixed capital and working capital requirements. Table- 4 shows that most of the respondent's source of capital comprise from family and own fund, which consists of $64 \%$ and $14 \%$ of the respondents interviewed respectively. Loan from a commercial bank $(2 \%)$ represent small percentage and from financial institution carry $(10 \%)$. Finance from friend and from other person represents $4 \%$ and $2 \%$ of the respondents respectively. Other person represents relatives, neighbors', local lenders etc. $2 \%$ uses both finance from family and other person. Another $2 \%$ uses both own fund and from family. No one of the respondents uses cooperative bank as a source of start-up capital. From this it can be said that, problem of finance is not so crucial in Sylhet city, as the pioneer source of capital consists of own fund and family. (AlHossienie, 2011) founds that, the formal sector is not contributing much in expanding women entrepreneurship in Sylhet city. 
Table 5: Initial investment and no. of employees in the business

\begin{tabular}{|l|l|c|c|}
\hline Investment and employees & No. of respondents & Percentage \\
\hline Initial capital investment & Less than 5 lakh & 43 & 86 \\
\cline { 2 - 4 } & $5-10$ lakh & 6 & 12 \\
\cline { 2 - 4 } & $10-15$ lakh & 1 & 2 \\
\cline { 2 - 4 } & More than 15 lakh & 0 & 0 \\
\hline \multirow{5}{*}{ No. of employees } & Total & 50 & 100 \\
\cline { 2 - 4 } & Below ten workers & 46 & 92 \\
\cline { 2 - 4 } & $10-20$ workers & 4 & 0 \\
\cline { 2 - 4 } & 21-30 workers & 0 & 0 \\
\cline { 2 - 4 } & 31-40 workers & 0 & 100 \\
\cline { 2 - 4 } & $41-50$ workers & 0 & \\
\hline
\end{tabular}

Source: Calculated from primary data

According to the Industrial Policy 1999, "Small Industries" are defined as industrial enterprises employing less than 50 workers and/or having a fixed capital investment of less than Tk. 100 million. (Awal, 2006). Here, all of the businesses can be categorized as small business considering the initial capital investment and employees involved. The study reveals the women are mostly interested in small business arena. $86 \%$ of the respondents invested less than 5 lakh. $12 \%$ and $2 \%$ were in 5-10 lakh and 10-15 lakh respectively. No one of the women entrepreneurs was investing more than 15 lakh.92\% of the respondents have below 10 workers and $8 \%$ of the respondents have 10-20 workers.

Table 6: Future career plan of women entrepreneurs

\begin{tabular}{|c|c|c|}
\hline Career Plan & No. of respondents & Percentage \\
\hline Continue the existing business & 42 & 84 \\
\hline Start a new business & 6 & 12 \\
\hline Get a job & 0 & 0 \\
\hline Quite the business & 1 & 2 \\
\hline Other plans & 1 & 2 \\
\hline Total & 50 & 100 \\
\hline
\end{tabular}

Source: Calculated from primary data

Table- 6 summarized the future career plan of the respondents. $84 \%$ of the respondents show their interest to continue their venture. They find their businesses profitable. $12 \%$ of the respondents want to start a new business beside the current one. It represents the interest regarding entrepreneurship of Sylheti women. Only $2 \%$ want to quite the business. $2 \%$ of the respondents have other plans which consist of going abroad. No one of the respondents wants to get a job by discontinuing the venture.

\section{Motivation behind choosing the entrepreneurial career}

Table 7: Who motivated them to be an entrepreneur?

\begin{tabular}{|c|c|c|c|c|}
\hline \multicolumn{3}{|c|}{ Motivators } & No. of respondents & Percentage \\
\hline \multicolumn{3}{|c|}{ Self-motivated } & 31 & 62 \\
\hline \multicolumn{3}{|l|}{ Friend } & 4 & 8 \\
\hline \multirow[t]{2}{*}{ Family } & Parents & 07 & \multirow[t]{2}{*}{15} & \multirow[t]{2}{*}{30} \\
\hline & Husband & 08 & & \\
\hline \multicolumn{3}{|l|}{ Others } & 0 & 0 \\
\hline & 50 & 100 \\
\hline
\end{tabular}

Source: Calculated from primary data 
Most of the respondents (62\%) mentioned that, they were self-motivated when they started their business. $30 \%$ of the respondents were motivated by their family which include parents and husband. After marriage it is most important to have the permission and helping hand of hubby to continue the venture. The socio-economic situation of Bangladesh binds the women to have the consent of husband before doing something. Women play many roles (daughter, mother, wife, entrepreneur etc.) and they have much social tasks than men which are demanded by the family. So, after marriage it is crucial to have the support of husband's family to successfully run their enterprise. Only $8 \%$ of the respondents are motivated by their friends (Table-7).

Table 8: Major reasons to start business

\begin{tabular}{|l|c|c|}
\hline Reasons & No. of respondents & Percentage \\
\hline Generating income for the family & 14 & 28 \\
\hline Continuation of family business & 4 & 8 \\
\hline Gaining economic freedom & 4 & 8 \\
\hline Be self-dependent & 18 & 36 \\
\hline Self-employment & 4 & 8 \\
\hline Creating job opportunity for others' & 3 & 6 \\
\hline Unavailability of preferred vacancy & 0 & 0 \\
\hline Training/Education & 2 & 4 \\
\hline Having owned ideas & 0 & 0 \\
\hline Adequate supply of capital & 0 & 0 \\
\hline Pass leisure time & 0 & 0 \\
\hline To upgrade social status & 0 & 0 \\
\hline Inspired by some organization & 1 & 2 \\
\hline Total & 50 & 100 \\
\hline
\end{tabular}

Source: Calculated from primary data

Table-8, summarizes the major reasons to start the business. Be self-dependent (major reasons of $36 \%$ respondents) and generating extra income for the family (pivotal reasons of $28 \%$ respondents) triggered women to be an entrepreneur. Other reasons (continuation of family business, for economic freedom, self-employment) consists same percentage each $(8 \%)$. Some of the respondents mentioned that, they want to create job for others and this is their main reason. This group represents $6 \%$ of the respondents. Training/Education in their related field of business also gives stimuli to start the venture. $4 \%$ of the respondents are in this group. $2 \%$ of the respondents are inspired some organizations.

Motivating factors create an urge and this impels women to start their business venture. Each women entrepreneurs drive by their most pressing motive.

\section{Challenges faced by women entrepreneurs}

In every way to success there are some obstacles. For achieving the goal, one must sweep away these hindrances. 
Table-9: Challenges of women entrepreneurs

\begin{tabular}{|c|c|c|c|c|c|c|c|}
\hline Statements & $\begin{array}{l}\text { Strongly } \\
\text { disagree }\end{array}$ & Disagree & \begin{tabular}{|c|} 
Neither agree \\
nor disagree
\end{tabular} & Agree & $\begin{array}{c}\text { Strongly } \\
\text { agree }\end{array}$ & Mean* & $\mathrm{SD}^{*}$ \\
\hline $\begin{array}{l}\text { 1. Family members were not } \\
\text { agreeing with my decision } \\
\text { to be an entrepreneur. }\end{array}$ & 28 & 18 & 1 & 3 & 0 & 1.58 & 0.81 \\
\hline $\begin{array}{l}\text { 2. I could not manage start-up } \\
\text { capital very easily to start } \\
\text { the venture. }\end{array}$ & 10 & 23 & 6 & 11 & 0 & 2.36 & 1.04 \\
\hline $\begin{array}{l}\text { 3. It is very hard to manage } \\
\text { working capital. }\end{array}$ & 4 & 16 & 6 & 22 & 2 & 3.04 & 1.12 \\
\hline $\begin{array}{l}\text { 4. Required training/course } \\
\text { facilities are not available in } \\
\text { Sylhet. }\end{array}$ & 6 & 9 & 2 & 21 & 12 & 3.48 & 1.35 \\
\hline $\begin{array}{l}\text { 5. There are lacks of different } \\
\text { skills (management/ } \\
\text { marketing etc.) to conduct } \\
\text { the business. }\end{array}$ & 4 & 12 & 7 & 20 & 7 & 3.28 & 1.21 \\
\hline $\begin{array}{l}\text { 6. Political influences hamper } \\
\text { my/our entrepreneurial } \\
\text { activity. }\end{array}$ & 7 & 5 & 7 & 18 & 13 & 3.5 & 1.35 \\
\hline $\begin{array}{l}\text { My suppliers are not very } \\
\text { co-operative/supportive. }\end{array}$ & 17 & 23 & 4 & 5 & 1 & 2 & 1.01 \\
\hline $\begin{array}{l}\text { 8. Infrastructural problems } \\
\text { (water/electricity/gas/tran } \\
\text { sportation etc.) are very } \\
\text { hazarders to run the } \\
\text { business. }\end{array}$ & 0 & 15 & 9 & 16 & 10 & 3.42 & 1.12 \\
\hline $\begin{array}{ll}\text { 9. } & \text { Inadequate technological } \\
\text { knowledge creates obstacles } \\
\text { in our way to do business. }\end{array}$ & 4 & 13 & 8 & 21 & 4 & 3.16 & 1.14 \\
\hline $\begin{array}{l}\text { 10. Social attitude is } \\
\text { conservative for women } \\
\text { entrepreneurs. }\end{array}$ & 4 & 9 & 2 & 20 & 15 & 3.66 & 1.30 \\
\hline $\begin{array}{l}\text { 11. Gender discrimination } \\
\text { creates hindrance in the } \\
\text { way of success. }\end{array}$ & 4 & 2 & 5 & 18 & 21 & 4 & 1.19 \\
\hline
\end{tabular}

Source: Calculated from primary data

*Mean value greater than the midpoint of 5 or 2.50 indicates challenges.

* Smaller SD (standard deviation) indicates lower dispersion among the responses in each statement.

Table-9 shows different obstacles that can hinder the way of women entrepreneurs in their way to success. The traditional thinking about women can bind them within the four wall of home. Women carry more social responsibility than man. Sometimes the mentality of family members creates pressures. Managing enterprise can sometimes impeding to complete the social responsibility. That can raise scurrilous language from family and this play a role of negative to inspiration. The initial consent and continual assistant is very much crucial to continue the venture successfully. In response to the statement "family members were not agreeing with my decision to be an entrepreneur"- 28 of the respondents were strongly disagreeing. Here the mean value (1.58) and the standard deviation (0.81) reveals that, women are not facing problems by their family. That means, the women entrepreneurs in Sylhet city are getting co-operation of their family members. A study conducted by 
(Rahmatullah and Zaman, 2014) reveals that, women entrepreneurs did not feel that having their own business affected their roles as spouse, parent or homemaker very much. Their study result shows low levels of work-family conflict in their spousal or parental roles.

23 of the respondents are disagree with the statement- "I could not manage start-up finance very easily to start the venture". The mean value (2.36) and standard deviation (1.04) indicates, accumulating start-up capital is not posing a problem to most of the women entrepreneurs of Sylhet city and they are solvent to start their venture. A study conducted by (Al-Hossienie, 2011) found that, most Sylheti women are financially sound enough to start their business without financial constraints.

Working capital management is very essential to bear day to day expense. Here, 22 of the respondents were agreeing with the statement- "It is very hard to manage working capital". Mean value (3.04) and standard deviation (1.12) also reveals that, women are facing challenges to gather working capital in Sylhet city. One of the respondents stated- "For developing my business I need sufficient working capital, but I am facing problems. I can't overcome it because of high interest rate of loan."

Receiving training is crucial to the advancement in profession. 21 of the respondents were agreeing with the statement- "Required training/course facilities are not available in Sylhet." So, it can be said that, women are not getting sufficient training from Sylhet and there are lack of training facilities. The mean value (3.48) and Standard Deviation (1.35) also indicating, the women in Sylhet city facing problem due to training facility. The research by (Al-Hossienie, 2011) also shows that among the women entrepreneurs in Sylhet only 46.8 percent have received training, while the remaining 53.2 percent did not receive any training regarding their profession. A study conducted by (Anis and Hasan, 2013) on Woman Entrepreneurs of Small and Medium Enterprises in Rajshahi Area: Opportunities and Challenges, $38 \%$ of respondents are strongly agreed that training facilities are inadequate whereas $14 \%$ of respondents are strongly disagree with the statements because they believe training facilities are adequate enough.

To face the competitive business world, it is urgent to have some skill which is essential for running the venture. Entrepreneurs are the pioneer of innovation. They innovate new ways of doing business. To reach the target customer it is necessary to understand the market and it is quite impossible properly without the marketing knowledge. For utilizing the factors of production it is necessary to have management skill. The survey result shows that, 20 of the respondents are agreeing with the statement-"There are lacks of different skills (management/marketing etc.) to conduct the business." Also, 12 of the respondents are disagreeing with this statement. Mean value (3.28) represent the lack of different skills as challenge of women entrepreneurs. Here the Standard Deviation is 1.21.We should realize that lack of managerial efficiency can create laggard performance. To manage labor, production, finance, research and development the management skill is immence.

The stability of a country's environment is much conducive to increase the entrepreneurial career. Politics is a greater part of the environment. Different types of political attempt can hinder the way of entrepreneurship. (Khanka, 2009) argues that we also regard security to be a significant factor for entrepreneurship development. This is reasonable too because if individuals are fearful of losing their economic assets or of being subjected to various negative sanctions, they will not be inclined to increase their insecurity by behaving entrepreneurially.

In response to the statement- "Political influences hamper my/our entrepreneurial activity." 18 of the respondents are agreed with this and 13 are strongly with this statement. Mean value (3.5) also indicate it as a problem regarding entrepreneurial growth. Here, the Standard Deviation is 1.35 . 
Responding the statement- "My suppliers are not very co-operative/supportive," 23 of the respondents are disagreed, and 17 are strongly disagreed with this statement. Suppliers' cooperation and assistance hardly need for the smooth flow of business operation. Final products' quality and timely delivery most of the time depends on suppliers performance. The respondents' responses and the mean value (2) and Standard Deviation (1.01) indicate that women entrepreneurs in Sylhet city are getting co-operation from their supplier.

Infrastructural problems can tremendously hamper the business. Sometimes the wrong choice of location, lack of water supply, irregular supply of electricity and gas, transport bottleneck can create the haphazard situation. "Infrastructural problems (water, electricity, gas, transportation, etc.) are very hazardous to run the business." This statement contains mean value (3.42) and Standard Deviation (1.12) shown it as a challenge. Here, 16 of the respondents are agreed with the statement and 10 strongly agree.

Inadequate technical know-how is a reason for underperformance in this digital age. The outdated process can waste energy, time, labor and other valuable resources. Lack of technological knowledge deters women entrepreneurs from using modern equipment. Using this equipment can uplift their profit; they can perform their work effectively and efficiently. In response to the statement-"Inadequate technological knowledge creates obstacles in our way to do business." 21 of the respondents are agreed with this. The mean value (3.16) indicates a lack of technological know-how pose a challenge for women entrepreneurs in Sylhet City. The Standard Deviation is 1.14 in this statement.

For the advancement of society, it is imperative to cross the boundary of traditional thinking as the women can't be a business person. With the expansion of education, awareness, and self- respect, women involve in the nontraditional sector. Women are entering in the business world with their devotion to overcome the social barriers and to prove themselves. The conservativeness of society can create mobility barriers to women. 20 of the respondents are agreed with the statement, and 15 strongly agrees with the statement-"Social attitude is conservative for women entrepreneurs." The mean value (3.66) and the Standard Deviation (1.30) represents conservative social attitude as a challenge for women entrepreneurs.

Women are not treated equally to men. Sometimes greater preference and effort are given to the male child in a family. It can create lower education and training for women. Male dominated society makes a frame of women's occupation, ability, capacity. Society can't think that women also can show efficiency as the male can. Women are facing stiff competition and harassment from their male counterparts. Officials may reject their business proposal, and their application for granting loan as only they are female. Continual gender discrimination can create frustration in women entrepreneurs mind.

"Gender discrimination creates hindrance in the way of success"- in response 21 of the respondents are agreed with this statement. The mean value (4) and Standard Deviation (1.19) represents the gender discrimination as a challenge for women entrepreneurs in Sylhet city. Siddiqui (2012) founds in his study that, $88 \%$ of the respondents express gender inequality as a problem of women entrepreneurs.

\section{CONCLUSION}

The women entrepreneurs due to the deteriorating conditions cross the boundary of conservativeness. The government should take further steps to improvise the advancement of them. What women need for enterprises are coordination from the family, financial support, and the motivation from the environment (society and government). The right kinds of assistance bring women near the height where they can uphold their status as well as represent the country. Women have the potential and persistence to avail the opportunities initiated for them. Without proper incorporation of women in a country's economy, it is quite 
impossible to achieve the country's targets. To make the path of women entrepreneurship proper, it is imperative to introduce entrepreneurship courses in the educational institution of Bangladesh. Training is imperative for women entrepreneurs so that they can avail updated technology as technology can save time and money and labor. Women should be given long term, collateral free loan and credit with low interest rate. For encouraging female entrepreneurs it is necessary to create opportunities and reduce barriers.

If a nation understands the factors encouraging women toward an entrepreneurial venture, they can create conducive environment and can degrade the challenges. The study may help in this regard mostly in Asian country. This qualitative study is focused only on Sylhet City Corporation. Future researchers may cover other areas and do quantitative study. This paper can provide opportunity for further research concerning women entrepreneurship in Bangladesh.

\section{REFERENCES}

Ahmed, R., Shams, A. and Rony, N.K. (2012), "The Young Entrepreneurs in Dhaka: reasons to be an entrepreneur \& hurdles to overcome as an entrepreneur", BRAC University Journal, Vol. IX, No. $1 \& 2$, pp.25-36.

Alam, S. (2015). Factors Affecting Job Satisfaction, Motivation and Turnover Rate of Medical Promotion Officer (MPO) in Pharmaceutical Industry: A Study Based in Khulna City. Asian Business Review, 1(2), 126-131.

Al-Hossienie, C. A. (2011), "Socio-Economic Impact of Women Entrepreneurship in Sylhet City, Bangladesh", Working paper [12], Bangladesh Development Research center, U.S.A, July.

Anis, Z. and Hasan, M. (2013), "Woman Entrepreneurs of Small and Medium Enterprises in Rajshahi Area: Opportunities and Challenges", International Journal of Scientific and Research Publications, Vol.3 (8/August), pp.1-13

Awal, A. (2006), "SMEs in Bangladesh", CACCI Journal, Vol. 1, pp. 1-19.

Charantimath, P. M. (2012), Entrepreneurship Development $\mathcal{E}$ Small Business Enterprises, $7^{\text {th }}$ Ed. India: Swan Press.

Chowdhury, S. and Rahman, M. (2014), “The Potentiality of Women Entrepreneurs in Bangladesh with Special Reference to Sylhet Region", Global Disclosure of Economics and Business, Vol. 3 (3/2014), pp. 18-26.

Firoz, F., \& Alam, M. (2015). Sustainability of Self-Efficacy among Nascent Disable Entrepreneurs: A Case Study on Disable's Home. Asian Business Review, 5(2), 43-49.

Holt, D. H. (2000), Entrepreneurship: New Venture Creation, Fourth Indian Reprint, New Delhi: PrenticeHall of India Private Limited.

Kaushik, S. (2013), "Challenges Faced by Women Entrepreneurs in India", International Journal of Management and Social Sciences Research, Vol.2 (2/February), pp. 6-8.

Khanka, S. S. (2009), Entrepreneurial Development, $10^{\text {th }}$ Indian Reprint, New Delhi: S. Chand \& Company Ltd.

Kumar, D., Hossain, M., \& Nasrin, M. (2015). Impact of Non-Financial Rewards on Employee Motivation. Asian Accounting \& Auditing Advancement, $0 . \quad$ Retrieved from http://journals.abc.us.org/index.php/araf/article/view/650

Nawaz, F. (2009), "Critical Factors of Women Entrepreneurship Development in Rural Bangladesh", Working Paper [5], Bangladesh Development Research center, U.S.A, May.

Rahmatullah, M. \& Zaman, F. (2014), "Female Entrepreneurship in Bangladesh: Constraints, Motivation and Success", Bangladesh e-journal of Sociology, [Online], 11(2/July). pp. 65-77.

Reza, M., Gazi, M. and Doula, M. (2014), "Socio-Economic Impacts of Women Entrepreneurs in Bangladesh: Challenges and Anticipations", Banglavision, Vol. 13, No. 1, pp. 38-57.

Siddiqui, A. B. (2012), "Problems Encountered by Women Entrepreneurs in India", International Journal of Applied Research \& Studies, Vol. I (II/Sept-Nov), pp. 1-11.

Singh, R. (2012), "Women Entrepreneurship Issues, Challenges and Empowerment through Self Help Groups: An Overview of Himachal Pradesh", International Journal of Democratic and Development Studies, Vol. 1(1/October), pp. 45-58. 